\title{
6. Contesting the Goro Nickel Mining Project, New Caledonia: Indigenous Rights, Sustainable Development and the Land Issue
}

\section{CLAIRE LEVACHER}

\section{Introduction}

Since the middle of the 1990s, indigenous groups have become increasingly active in the international arena with a view to publicising the social, environmental, health and political impacts of mining projects on their lands, territories and resources. The extent of this activity contributed, in particular, to the formulation of Articles 26-32 of the United Nations Declaration on the Rights of Indigenous Peoples, which was adopted in 2007. ${ }^{1}$ These articles establish the right to redress, compensation, protection of the environment and, beyond this, the right to self-determination

1 The articles in question concern the rights of indigenous peoples to lands, even in the absence of the allocation of formal property rights by the state; the recognition of this by the international community of states and the protection of the territories involved; the right to redress, restitution and compensation; the conservation of the environment and the production capacity of the lands; the mitigation of the adverse effects of production on the lands; and the absence of military activity. Article 32 states, finally, that: 'Indigenous peoples have the right to determine and develop priorities and strategies for the development or use of their lands or territories and other resources.' The states 
in terms of development options. In fact, the mobilisation of environmental issues in the context of global mining conflicts frequently constitutes an argument for the rejection of industrial mining projects. And yet, the association of indigenous struggles with environmental battles is not systematic, particularly in countries in which the mining sector can constitute a development tool for the indigenous population (Ali 2009). This is precisely what I propose to investigate here through the examination of a conflict involving the company INCO (subsequently Vale) in relation to the Goro nickel mining project in the South Province of New Caledonia, which concluded in 2008 with the signing of a 'sustainable development pact' between the local Kanak population and the company-the Pacte pour un Développement Durable du Grand Sud.

Based on the results of a qualitative study carried out as part of a doctoral thesis from 2011 among the inhabitants of the municipality in question, institutional representatives, employees of the Goro Nickel Project, and other political actors, I aim to revisit the phases of a conflict with the mining company that has already been examined from both environmental (Horowitz 2009, 2010, 2012) and political (Demmer 2007, 2012; Djama 2009; Le Meur 2010) perspectives. The various twists and turns in this mobilisation process, between 2001 and 2008, illustrate the progressive formalisation of an argument relating to the rights of indigenous peoples, which links the question of development with management of the natural environment.

The different actors who emerged during this period expressed different representations of links between people and land. The questions posed here concern the extent to which these representations enable us to gain a better understanding of the 2008 agreement, and what they tell us about the different actors' visions of development. I begin this analysis with an account of the contemporary history of New Caledonia that will facilitate an understanding of the emergence of a discourse of indigenous rights in the country. I shall then revisit the different phases of the conflict with a view to comparing the economic and environmental aspects of the project, hence enabling a reinterpretation of the 2008 agreement. Thus I hope to highlight the issues on which it was silent, and investigate the role of the local public authorities and their own concept of development.

are obliged to consult them in relation to the use or exploitation of minerals, water and other resources and must establish redress mechanisms to mitigate harmful effects on the environmental, economic, social, cultural or spiritual levels. 


\section{New Caledonia and the Indigenous Question}

New Caledonia is currently involved in a process of 'negotiated decolonisation' triggered by the Matignon-Oudinot Agreements of 1988 and confirmed by the Nouméa Agreement of 1998. These agreements contained provisions for the organisation of a referendum between 2014 and 2019 that would define the country's future and organise the transfer of powers from the French state to New Caledonia. The country has since been divided into three provinces (North, South and Loyalty Islands) with a view to promoting its economic, social and political 'rebalancing'. The Nouméa Agreement provides for the legal and political recognition of the historical legitimacy of the Kanak people's ties to the land. It recognises the existence of a Kanak people distinct from French people, and designates them as the basis for the construction of a 'common destiny' with the territory's other ethnic groups. The recognition resulting from these agreements constituted a new stage in the history of the indigenous question in New Caledonia.

During the colonial period, the indigenous people were subjects of the French empire. Their categorisation by the French colonial administration was based on two factors: the recognition of a separate (customary) legal system described as a droit civil particulier ('special civil law') (Saada 2003: 12-15), and the need of the European colonists to more clearly mark the legal boundaries between French citizens and the subjects of the empire. These boundaries were defined by the decree of 22 January 1868, which established the collective ownership of Melanesian territory by instituting the 'reserve' and the 'tribe' (tribu) as both land-based and administrative units. ${ }^{2}$ The land tenure regime resulted from the seizure of Kanak lands by the colonial settlers and caused the progressive regrouping and displacement of relatively dispersed settlements and political structures.

Prior to the colonial period, the customary Kanak chieftaincy was a political space delimited by the topographical landmarks of a 'country' (Bensa 1992), and the social identities of Kanak clans were based on group itineraries that provided the basis or justification for the appropriation of an area of land (Naepels 2006). The chieftaincies were broadly (re)structured by the colonial administration, which established a form of indirect rule in several steps over a period of almost 40 years (1860-1900) by creating a system of

2 The term tribu originates from the segregation of the Kanak populations of New Caledonia in reserves, which was first carried out in 1876 (see Merle 1999). 
administration in which the grand chefs ('big chiefs') had authority over a district in which they nominated the petit chefs ('little chiefs') who were in charge of each tribu (Bensa 2000).

The 1970s witnessed the emergence of independence claims based on the recognition of the historical legitimacy of the Kanak people and their culture, and a demand for the right of self-determination. In many ways, the discourse on the link with the land developed by the Kanak nationalist movement during the 1970s adopted an indigenous rhetoric in the strict sense. It aimed to demonstrate the attachment of the people to their lands and the antecedence of this attachment. ${ }^{3}$ What was involved here was the constitution of the political entity of the 'Kanak people' and the legitimisation of the right to accommodate the 'others'- the non-indigenous people who arrived with colonisation. The MatignonOudinot and Nouméa agreements confirmed and substantiated this recognition through the establishment of new institutions. In the political domain, the chieftaincies now have their own representative bodiesthe Sénat Coutumier (formerly the Conseil Coutumier) and the eight customary area councils. Although it does not have any executive powers, the Customary Senate has a recognised right to be consulted on any proposals for laws or policies that 'concern the Kanak identity' (under Articles 1.2.5 and 2.1.4a of the Nouméa Agreement) or Kanak land (under Article 1.4). With regard to the latter, however, the recognition is mainly reflected in the establishment of the Agence de Développement Rural et d'Aménagement Foncier (ADRAF), which is responsible for implementing the rehabilitation of degraded land by means of a process of land reform—a process that is still underway today. The 'customary lands' involved in this process include the original reserves and the areas restored to customary ownership since 1946. They are governed by customary law, subject to the customary authorities, and are inalienable.

With the emergence of the United Nations discourse on the rights of indigenous peoples, the period launched by the Matignon-Oudinot Agreements saw the development of a new interpretation of the indigenous question in New Caledonia. By focusing reflection on the maintenance and defence of Kanak specificity in the context of the future statewhether independent or not-the change in the local political idiom

3 In French scholarship on Ancient Greece, it was the acknowledgment of a shared origin and antecedence that provided the basis for the establishment of specific rights, especially in Athens (Loraux 1996; Detienne 2003). Kanak demands were based on the same principle. 
was clearly rooted in the 'politics of recognition'. This movement opened with the establishment of the Association pour la Commémoration de l'Année des Peuples Indigènes en Kanaky in 1993, and its successor, the Conseil National du Peuple Autochtone, against the background of the 'international decade of indigenous peoples' (Monnerie 2005; Demmer 2007). It testified to the multiplicity of possible interpretations of the future of New Caledonia, which ranged from the exercise of sovereignty within the French state to full and complete independence (Graff 2012).

The United Nations discourse on the rights of indigenous peoples was mobilised with particular reference to the management of natural and mineral resources. In effect, the Nouméa Agreement imposed the development of a schéma minier ('mining plan') through Article 39 of the Organic Law, which stipulated that the ways in which natural resources are exploited had to be redefined. The mining sector represents the country's second most important economic resource after transfers from the French Government, and was the subject of tough negotiations in the lead-up to the signature of the Nouméa Agreement. While the establishment of a nickel smelter in North Province was central to this process (see Chapters 2 and 3, this volume), the mining plan made no mention of the construction of another nickel processing plant on the Goro site in South Province. In 2002, a new association, Rhéébu Nùù ('Eye of the Country'), was established on the initiative of the chieftaincies of Goro, Unia and Touaourou in the municipality of Yaté, where the Goro project is located. The aim of this body was to support indigenous rights as defined in the United Nations framework and to protect the environment. Following several years of conflict with the developersfirst INCO and then Vale — the Pact for the Sustainable Development of the Great South was signed in September 2008.

This agreement rests on three pillars. The first explicitly provides for reparation through afforestation, the training of environmental technicians and the setting up of plant nurseries. The second establishes a consultative customary environmental committee to act as an intermediary between the company and the populations in the area around the project, and to ensure the participation of the customary bodies in environmental monitoring

4 The Canadian transnational corporation INCO acquired the mining titles to the Goro massif in 1992. This company was acquired by Vale, a Brazilian transnational corporation, in 2006. 
activities. The third involves the establishment of a corporate foundation with a mission to involve the local populations in socioeconomically and culturally sustainable development'.

The conflict with the company appeared to be rooted in the process of decentralisation or 'provincialisation' that resulted from the MatignonOudinot Agreements and the unequal nature of power relations within and between the provinces. While the dominant political forces in North Province are pro-independence, South Province is dominated by loyalists who oppose the country's independence from France. This situation has enabled the fragmentation of pro-independence political positions between the provinces. Provincialisation promoted the emergence of claims for additional collective rights by the southern Kanaks in the management of issues that have a direct impact on them, especially the plant in Mont-Dore and the mine in Yaté. As a result, they got involved in an ongoing quest for the rebalancing of power relations with the mining company and the province, and the production of strategies and tools to achieve it.

On one hand, the conflict with the company was rooted in a context characterised by the weakness of the regulatory framework: it contributed to, and took shape within, a new process of 'bottom-up' public policy production (Le Meur et al. 2013). Hence, there was a growing awareness of a situation of dependence at the local level, to which the claim for collective rights to the management of resources constituted a response.

On the other hand, the conflict also represented a struggle for recognition. ${ }^{5}$ It was the customary authorities that initiated this quest for new rights, aimed at defining the territories and modalities of the exercise of their own power. Opposition to the mining project involved different levels of power and representations of the political arenas that emerged rapidly at the interface of the development and environmental issues raised by construction of the plant.

5 According to Taylor (1994), the concept of recognition is critical to an understanding of social conflict in the context of modern forms of nationalism, minority claims, and the quest for new rights. Struggles for recognition borrow from numerous registers that play a role in the reconstruction of arguments based on existing hybrid concepts of community and identity (Jacob and Le Meur 2010). 


\section{Development and the Indigenous Shaping of Land Legitimacy}

The desires and fears of the population with regard to this mining project emerged in the wake of the social impact study commissioned by INCO and carried out by the Géosystèmes, Environnements et Cartomatique Océaniens research unit of the Université Française du Pacifique. They can be summarised as having three focal points: jobs, environmental management and Kanak cultural specificity (Jost 1998). This and subsequent studies revealed elements comparable to the concerns of the people affected by the Koniambo nickel project in North Province (see Chapters 2 and 3, this volume). It was predicted that the Koniambo project would have 'positive economic impacts through employment and training, that these economic effects [would] be shared equally between the people living in the project area and, finally, that the negative consequences on the level of the ecological environment [would] be minimised' (Grochain 2007: 216).

The question of employment was initially considered at the level of the tribus in the area bordering the project. The tribus of Yaté were interested in the development of an economic system that would be able to combine customary principles with those of the market economy by using the institutions of the 'special civil law', especially the associations known as 'local groups with special rights', groupements de droit particulier local (GDPLs). ${ }^{6}$ However, the multiple economic initiatives that emerged at this time were caught up in a context characterised by profound divisions, and involved a competition for economic activities and spatial legitimacy between the two municipalities affected by the mining project-Yate and Mont-Dore.

From the time of construction of the pilot plant in 1999, the establishment of the mining complex rekindled divisions between the two municipalities that were closely linked with an older contest over the spatial boundary between them (Frouin 2010). The tribus in each of the municipalitiesthree from Yaté and two from Mont-Dore-initially aimed to establish their own companies, and in 1999 they tried to create a form of economic

6 The GDPL is a legally recognised structure, with a legal personality, originally created to promote economic activities on customary lands, but also deployed in the context of land claims. It brings together individuals who are connected through customary ties-within a family, clan or tribu - and is managed under customary law. 
organisation based on a land claim made by the chieftaincies of the two municipalities. In 2001, the same five tribus made another attempt to establish a single GDPL in order to organise the subcontracts in all areas of economic activity relating to the proposed smelter-including transport and logistics, earth-moving during the construction phase and subsequent extraction of the ores (Anon. 2001). However, a GDPL representing the tribu of Goro quickly broke ranks with this structure.

The withdrawal of the Goro tribu had the effect of refocusing the earlier GDPL within the municipality of Yaté alone. The municipal authority of Yaté established a monitoring committee in 2001, which was meant to cover all of the construction activities associated with the project. ${ }^{7}$ This was a forum through which the elected and customary representatives could regulate local individual initiatives by ensuring that they became integrated into the collective management of the mineral wealth. In 2002, this process resulted in the establishment of a model for the participation of the population of the Grand Sud ('Great South'), which would later be replicated in North Province (see Chapter 2, this volume). This involved the establishment (in 2003) of a joint venture (société par actions simplifiée) called SAS Goro Mines, whose main function was to allocate projectrelated subcontracts to local businesses.

This model (Figure 6.1) is based on the institutions associated with the 'special civil [Kanak] law', namely the customary authorities and the GDPLs, combined within a type of non-trading company known as a société civile de participation (SCP). In this instance, the Xéé Nùu SCP included all of the investors originating from the municipality, which meant that each tribu established had its own GDPL for the purpose of collective shareholding, alongside those 'small shareholders' who wished to make individual investments. The Xéé Nùu SCP itself held the majority of shares in SAS Goro Mines, and also had shares in another company called Sud Restauration. In terms of distributing the revenues generated by the mine, SAS Goro Mines was conceived as a way of combining the companies already positioned to secure subcontracts for the pilot plant, and then to accommodate other local companies that were yet to be established. The revenues that accrued to the SAS would be shared through the SCP

7 This body included representatives of the mining company (Goro Nickel), the Betchel HatchTechnip consortium, which was in charge of the building works; the Chamber of Commerce; government officials, including personnel from ADRAF; local experts; the customary authorities of the Djubéa-Kapume area; and the elected representatives of the municipality. 
partnership between the different collective and individual shareholders. To avoid conflicts regarding the allocation of contracts between the entrepreneurs, and to ensure equal representation of all the tribus and clans of the Yate municipality, the SCP also had the task of nominating managers for the companies participating in the SAS. The province was also involved in supporting the establishment of local companies, particularly in the catering sector, through a development fund called PROMOSUD, which was a separate element in the model of participation.

\section{SHAREHOLDING}

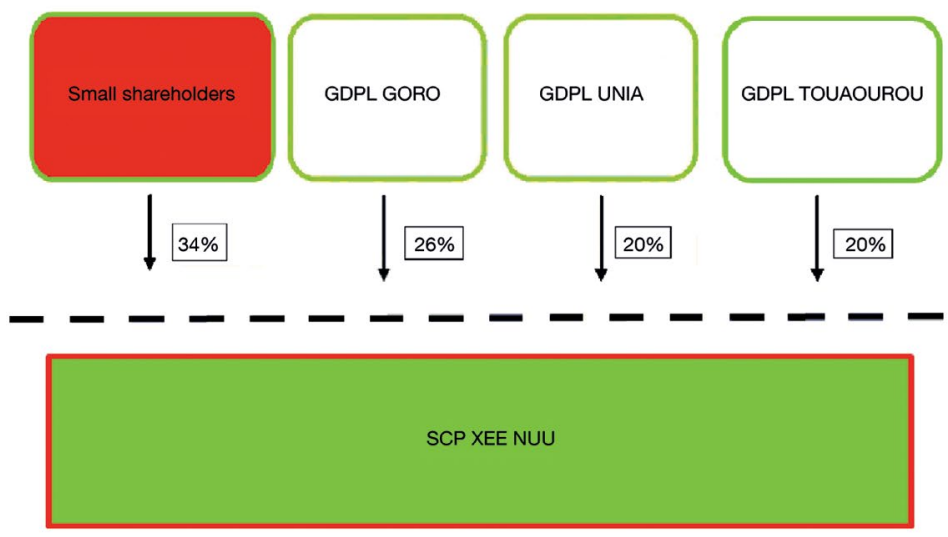

\section{SUBSIDIARIES}

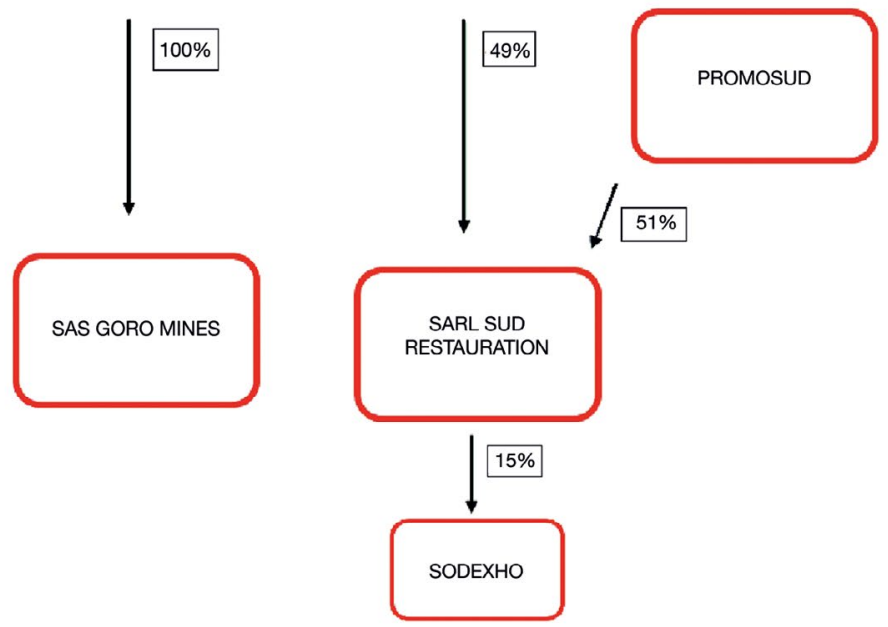

Figure 6.1 The model for participation of the population of the Grand Sud in development of the mining project.

Source: Author's diagram. 
From a perspective akin to that described by Bainton (2009) in relation to the Lihir mine in Papua New Guinea, the aim of these arrangements was to provide an economic basis for the customary legitimacy of the municipality's tribus. The adoption of this approach made it possible to circumvent the fact that the mine is not situated on land recognised as customary by the state. Within the total area of the municipality of Yaté, customary land is limited to a small coastal strip. Accordingly, the tribu of Goro, which is located on the seashore, at the foot of the plateau where the mining takes place, was recognised by the municipality's other tribus as having a legitimate land-based claim to the area in which the mine is located. This is reflected in the model (Figure 6.1) by the greater number of shares in the SCP partnership held by the Goro GDPL. This extension of spatial claims without actual land acquisition, to achieve the recognition of customary legitimacy in the context of mining projects, was already observed in Thio (see Chapter 5 , this volume). ${ }^{8}$ In the case of Yaté, the recognition of this group's rights to the mining area enabled the negotiation of a share in the economic activities of the mining company, even while the municipality's business base remained weak in terms of volume, skills and experience. This process may be viewed as a form of compensation that acts as a driving force in the development of the customary groups and, by extension, the municipality (see Bainton and Macintyre 2013: 142). However, in practice, it encouraged a tribal appropriation of relationships with the mining company, as evident in the fact that the son of the great chief of the Goro tribu was appointed as managing director of SAS Goro Mines.

The establishment of the SAS did not instantly result in its official recognition by the mining company as a partner and exclusive point of contact for the management and allocation of subcontracts, nor did this recognition feature in the 2008 agreement with the customary leaders of the region. The recognition in question was only achieved in 2011, with the signing of a framework agreement between the SAS and the mining company, but one year later, there was a change in the management of the SAS, and the new management got involved in a land claim on the Goro plateau. This claim demonstrated the difficulty posed by the problem of land tenure. Making the SAS into the sole preferred partner

8 It should be noted that a land claim with land acquisition had been attempted in 1994, when two clans from Goro requested that South Province grant them two plots of land located in the municipality of Mont-Dore, in areas bordering or intersecting the project zone. An arbitration process resulted in the reduction of the 5,000 hectares requested to 400 (Jost 1998: 490). 
of the mining company entailed a recognition of the Goro company's managing director as the 'landowner' of the site. It thus promoted competition for appropriation of the land (Kowasch 2012: 212-13), as well as the relationship with the mining company that was based upon it. Throughout this first phase in local dealings with the mining company, it appeared that the tribus were the instigators of economic initiatives, and that they were organised around the authority of the chieftaincies in the context of claims that extended beyond the reallocation of land rights to the appropriation of relationships with the mining corporation. The emergence of a discourse about natural resources, shaped by the international discourse of indigenous rights, confirmed this tendency to extend highly localised claims by reformulating the relationship with the land and natural environment.

\section{International Indigenous Rights and Spatial Legitimacy}

Through these initial attempts at economic organisation on the level of the chieftaincies, it would appear that the desire to participate in mining development in the region constituted a factor that determined the call for land-based legitimacy in dealings with the mining company. The transformation of the monitoring committee of the municipal authority of Yaté into an indigenous committee (Rhéébu Nùù) formalised the idea of a right to development based on a public discourse of legitimate control over geographical and political territories. Two shifts arose from this process: the first was political, and resulted from the recognition of the link with the land, while the second concerned the reformulation of Kanak perceptions of the natural environment. This dynamic was based to a large extent on claims that were both highly localised (on the level of the chieftaincies) and more extensive (at municipal and provincial levels). The appearance of elements originating from international discourse of indigenous rights also endorsed the spatial and discursive extent of the claims being made on the mining company.

When the monitoring committee of Yaté municipality became the Rhéébu Nùù Committee in 2002, the change of name was indicative of a change in structure. The collective body thereafter claimed to represent the chieftaincies of the south in a process that was supposed to overcome the aforementioned economic and political divisions, but 
which also invoked the international rights of indigenous peoples that were still in the process of being formalised in the United Nations arena. The move by the chieftaincies to take control of the development process came to be part of a political process that made new connections between natural and political territories. This process went beyond the political recognition provided by the agreements, which was based on the idea of a link with the land, since it involved the extension of the customary authorities' prerogatives to matters beyond those usually reserved to them. For one of the leaders of Rhébu Nùu from the Unia tribu, the process of colonisation created administrative territories that did not relate to the institutions of pre-colonial society, in which territories were based not only on areas bounded by natural features and clan itineraries, but also on the political links between chieftaincies. In his view, this ancient political system established the legitimacy of the customary authorities on the land where the mining plant is located and in their relationship with the mining company.

This spatial right of the chieftaincies was incorporated into the framework of the recognition of the link with the land by the Nouméa Agreement, but the ways in which it was exercised were defined with reference to the international rights of indigenous peoples. The 'Declaration on the Right over the Space and Natural and Cultural Heritage of Kanaky', commonly known as the 'Kanaky Declaration', was produced on 22 August 2002. It refers to the concrete implementation of 'the Kanak conception of the relationship with the space and the natural and mining heritage', especially through the principle of free, prior and informed consent. This principle, as defined in Article 19 of the United Nations Declaration on the Rights of Indigenous Peoples, involves consultation of indigenous peoples by states prior to the approval of any measure that could have a direct impact on their rights, especially when it involves activities carried out on traditional indigenous territories.

The Kanaky Declaration specified the conditions for the implementation of the principle in New Caledonia, including consultation of the clans directly concerned, the chieftaincy, the neighbouring chieftaincies, the customary council and the Customary Senate. In many ways, the declaration may be considered as the founding charter for indigenous claims regarding the management of natural resources in New Caledonia. It linked the local customary authorities with the Customary Senate, 
and rendered visible the demand for participation in development and control of the territories that concern these authorities. The Kanaky Declaration states that:

In future, all major economic projects involving the exploitation of renewable and non-renewable natural resources shall involve the establishment of ways that enable the Kanak customary authorities to be actors ... The indigenous Kanak people shall be actors in the definition of development plans [emphasis added].

The second aspect of the chieftaincies' spatial management claim concerned the reformulation of Kanak perceptions of the natural environment. It aimed at the integration of such perceptions into the international legal and policy framework relating to indigenous peoples. The newly conceived Kanak role in the protection of nature was based, in particular, on legal texts such as those produced by the United Nations Conference on Environment and Development in 1992, by the regional conferences held in Apia (1976) and Nouméa (1986), and by Article 8(j) of the Convention on Biological Diversity, which explicitly recognises the contribution made by indigenous communities to the conservation of the biodiversity of the regions they inhabit, thanks to their traditional way of life (Djama 2009: 55). This supported a discourse that not only made Kanak populations responsible for the protection of their own natural environments, but also cast them as a driving force for the establishment of environmental awareness at the national level:

What I would also like to clarify is that ... the intensification of the exploitation of resources ... raises the question of ... the role of the indigenous peoples with respect to the conservation of their environment and, hence, the country's environment ... In a way, there is a need for the entire country to be at peace with nature ... There is a need today to get this process underway through the rehabilitation of this concept of the natural heritage, the responsibility for which goes back to the indigenous peoples. (Mapou 2002: 23)

The evolution of Rhéébu Nùu's discourse in support of environmental protection constitutes a twist in the relationship with the mining company, which involved a (re)construction of identity, while also extending the spatial extent of the claims being made. Through the environmental argument, local and regional identities, which were recognised as being based on the relationship with the land, became part of a kind 
of ethnogenesis (Morin 2006) — a global and legal identity within the United Nations arena. The major advantage of this (re)constructed identity was that it appealed to the creative and imaginative force of the law in a context characterised by a legal void with respect to mining and environmental issues.

The provincial plan for the exploitation of mineral wealth was only completed in 2008, and the mining and environmental regulations in 2009. The designation of the 'Lagoons of New Caledonia' as a UNESCO world heritage site was clearly enshrined in this process, and would mark the settlement of several years of technical struggles against the mining company for compliance with international environmental standards and greater respect for the environment. Hence, the environmental aspect of the Rhéébu Nùù Committee's indigenous struggle took shape in a strategic alliance formed with environmentalists-especially local environmental organisations-with a particular focus on protection of the lagoon. ${ }^{9}$ This alliance enabled the bundling of the expertise of the environmental organisations with the local people's concerns about the risks posed by pollution and dumping of heavy metal wastes from the processing plant. The focus on protection of the lagoon thus involved a shift in the nature of indigenous interests from the mining site towards the sea. The extension of the geography of the claims therefore contributed to the entry of new actors and arguments into the ranks of the opposition to the project.

\section{The Heritage in Question: Mining Rent at the Service of the Environment}

The 'heritage' question provides a key to understanding the extent of the coexistence of environmental and development concerns expressed by Rhéébu Nùù through its interest in land issues. It links the environment with all the forms of value that can be attributed to it-economic, political or cultural. The signatories to the Kanaky Declaration defined their conception of the Kanak natural heritage as one that had to serve the causes of development and spatial management through the collection of a rent calculated on the basis of the value of the mined ore-or what

9 This strategic alliance raised questions regarding the environmental studies carried out with respect to the mining project-whether impact studies commissioned by the developer or the numerous counter-studies commissioned by its opponents. 
would normally count as a kind of 'royalty' ${ }^{10}$ Hence, this patrimonial heritage assumes different dimensions that contribute to the economic, environmental, social and cultural shaping of the spaces and territories around the project. The discourse of the Rhéébu Nùu Committee established a link between the protection of the environment, the negotiation of economic rights to participate in the process of economic development, and the rights of the indigenous people through the definition of compensation for destruction of the environment that they considered as their property. This understanding of compensation was reflected in two specific demands: one for the creation of a municipal mining tax, and the other for the formation of a heritage fund for environmental rehabilitation.

Having been accused of wanting to negotiate the receipt of 'royalties', the indigenous leaders developed a more general point of view on the mineral tax regime at the national level, despite the fact that neither the plan for the use of mineral wealth nor the mining regulations, both of which were envisaged under the terms of the Nouméa Agreement, had actually been completed. The tax exemption measures of 2001 revealed the small share of benefits that the municipalities would be able to accrue from mining operations. The National Law on the Taxation of Nickel Mining for Major Metal-Processing Projects, which was passed in July that year, included corporate exemptions from business licensing taxes, property taxes, registration fees and general service taxes for a period of 15 years from the beginning of commercial operations. The mining tax payable to the municipality of Mont-Dore involved surcharges on these exempted taxes, and the reason why these surcharges only applied to Mont-Dore is that mining taxes are currently only levied on the processing of ore and not on its extraction. The demands of the Rhéébu Nùu leaders for a 'mining tax for the benefit of the municipalities and populations affected by this activity' (Anon. 2003) were made in this context of uncertainty about the definition and distribution of the economic benefits of mining both at the local level and for New Caledonia as a whole, where there were many possibilities offered by the reconstitution of the tax regime. As others saw it, a share of mining taxes constituted an alternative to the proposed acquisition of a stake in the mining company, in particular through a proposition for the buyback of part of the capital. The recognition of

10 While royalties are commonly defined as a kind of tax collected by the state or 'crown' in its capacity as the owner of subsurface mineral resources, customary landowners in Papua New Guinea have long been recognised as having an entitlement to a share of this type of mineral revenue. 
the link with the land depended on the greater economic involvement of the local population, whether by means of equity or taxation, since these appeared to be the only possible levers for obtaining real partnership and an effective commitment on the part of the mining company to the development of the region and the country. ${ }^{11}$

The Rhéébu Nùù Committee's detractors accused it of negotiating a tax regime that would solely benefit the chieftaincies, without regard for the discourse of environmental protection. In 2006, Philippe Gomes, the new president of South Province, firmly opposed the payment of any kind of royalties to the owners of the land on which one or more of the mines were operating, basing his argument on the view that 'the Caledonian industrial projects lead the local populations to be actors involved in development and not rentiers' (Pitoiset and Prandi 2006). While some people now acknowledge that they had envisaged such an outcome, they say it would have been abandoned quickly in favour of the current model of participation (Figure 6.1), which was conceived as a means of distributing the benefits equitably while favouring individual and clan-based economic initiatives and financial incentives. The municipal mining tax system also made it possible to ward off or avoid financial and land claims through the integration of the concerns of the chieftaincies and the municipality for local development on the same level. In this regard, another indigenous representative body, the Comité Autochtone de Gestion des Ressources Naturelles (CAUGERN), which was formed in 2005, has initiated a process of joint reflection by the chieftaincies that wanted to be involved in development and the municipalities that wanted to benefit from additional resources, since both believed themselves to be entitled to enter into a relationship with the mining company and to benefit from the associated economic spin-offs (Demmer 2012: 36; also Chapter 4 , this volume). ${ }^{12}$

From 2002, the demands of the Rhéébu Nùù Committee also involved the establishment of a 'heritage fund' that was, in the words of the Kanaky Declaration, to be 'determined on the basis of the intrinsic value of the processed primary resource'. So the declaration established the fact that providing employment was not enough, and that each cubic metre

11 A majority shareholding in the mining project was to be the route taken in the case of the Koniambo project in North Province (see Chapter 2, this volume).

12 This fusion of interests was achieved in Yaté through the municipal elections of 2008, which resulted in the election of a mayor from a list of Rhéébu Nùù candidates. 
of nickel extracted has an economic value that should be used as a basis for the establishment of a financial entity devoted to the promotion, restoration and protection of the Kanak natural and cultural heritage, in the name of the rights of the clans and chieftaincies to their 'natural space', and under their own political control. Rhéébu Nùu defined this fund in 2003 as 'the cornerstone of the indigenous process', and stated that it should also be based on what the Kanaky Declaration called the 'value of the replacement of the 1000 hectares of forest that had already been destroyed'. In 2004, the president of Rhéébu Nùù again raised the question of an output-based mining fee, to which the mining company responded by pointing out the lack of New Caledonian legislation in this area. In 2005, the question was back in the spotlight and expressed as follows:

It is essential that part of the mining wealth be used to compensate for the consequences of decades of exploitation. A special tax should be created to finance the environmental rehabilitation of the area damaged by the mine. (Frédière 2005)

The demands of the Rhéébu Nùù Committee and CAUGERN were completely in line with the thinking of the Comité Stratégique Industriel, which was established in 2010. This is a bipartisan body composed of government and mining company representatives, under the leadership of Anne Duthilleul, representing the French Government, which has been tasked with production of a mining and industrial strategy for New Caledonia. In 2005, a report by the Senate of the French Government on tax exemptions for the nickel processing plants expressed concern that a kind of 'freedom from tax' was being ordained, and preferred the adoption of a 'mining fee' of the kind proposed by Anne Duthilleul: 'it is essential that the local authorities be given the resources to fulfil their general interest functions; the interventions of the state cannot entirely replace the just and fair taxation of the mining sector' (quoted in Le Meur and Mennesson 2011: 9).

This suggestion was not completely rejected by the loyalist parties in New Caledonia, since one of them had drafted a proposal in 2004 for the creation of a heritage fund for the benefit of the populations affected by the Goro project. This proposal was not implemented, but there is now a de facto rehabilitation fund (the 'Nickel Fund') that redistributes the land taxes paid by the mining companies to the municipalities that have old mine sites in need of rehabilitation. 
As we can see here, the indigenous collective that initiated the battle with the mining project expanded the content and scope of its demands beyond the issue of environmental protection. Through defence of the natural environment, not only was the question of environmental conservation tackled but also the means of achieving it and, beyond this, the means of attaining sustainable development based on the collection of a mining rent.

\section{Conclusion: The Pact, Mining Rent and Sustainable Development}

I set out to demonstrate that different types of arguments were mobilised by the strategic groups that have constituted and transformed Rhéébu Nùu as an indigenous collective, while also subject to change in their own internal constitution. As a result, the rights of indigenous people have become rights that link environmental protection and rehabilitation with economic development. These rights have served in the negotiation of more specific rights to the management and administration of the projectaffected areas. The shift from a localised economic perspective towards a broader environmental one, in terms of both demands and actors, does not mean that the two approaches are mutually exclusive. This spatial and discursive expansion of the indigenous struggle had complementary impacts from the point of view of the legal provisions that emerged from it, and it also reflects different conceptions of sustainable development. ${ }^{13}$

The 'environmental turning point' in the battle against the industrial project has in a way contributed to shaping new questions for public policy by underlining the environmental effects of mining activities. The Environmental Regulations of South Province refer to the principle of consent, the establishment of an environmental compensation fund and the formalisation of environmental impact studies. The designation of the Lagoons of New Caledonia as a UNESCO world heritage site in 2008, and the establishment of New Caledonia's environmental monitoring agency, the Observatoire pour l'Environnement, in South Province in

13 In fact, the 'sustainable development' frame of reference only emerged on the interface between the mining sector and its local management in New Caledonia in the early 2000s. Until then, the development models were dominated by the transition from an 'assisted economy' (Freyss 1995) to economic independence based on mining rent, economic 'rebalancing' and state transfers (Sourisseau et al. 2015). 
2009, are events that clearly link environmental protection to mining development. They also raise new ways of thinking about sustainable development in New Caledonia. The strategy for the integration of sustainable development into provincial policy only took shape in 2007, by linking economic and environmental issues around ecotourism projects that were conceived as a form of compensation for the negative impacts of mining activities (Sourisseau et al. 2013). In this regard, South Province's absence from the Pact for the Sustainable Development of the Great South could be indicative of a sustainable development conception that is more focused on 'rurality' and on spatial conservation than on the regulation of the mining sector (Le Meur et al. 2013).

The pact itself made sustainable development into a point connecting the diverging interests of indigenous peoples and mining companies. While the former wanted to protect their natural, social and economic environment, the latter wanted to reduce the risk of facing more stringent legislation and greater civil society mobilisation (see O'Faircheallaigh 2011). As a point of overlap between international 'soft laws'-like the 'good practice guides' developed by the International Council on Mining and Metals or the Declaration on the Rights of Indigenous Peoplesthe pact tends to maintain the enclave logic inherent in projects of this type with a certain definition of sustainable development being applied to specific areas. For the customary people of the south, and for the Rhéébu Nùù collective in particular, the local implementation of sustainable development principles appeared to take root in forms of negotiation over the distribution of mineral resource rent. The local model of participation (Figure 6.1) highlighted two things: first, that landownership was not a sufficient basis for establishing a relationship with the industrial concern; and second, that the internal redistribution mechanisms would constitute a driver of development on customary lands, and especially of private economic initiatives.

The pact was also conceived as a form of compensation in the sense that it put an end to an abusive relationship. In this case, the recognition of customary rights did not unfold through the payment of rent to customary landowners in exchange for land acquisition by the state, as has been observed in Papua New Guinea (Strathern 1993; Filer 1997), but through the establishment of new mechanisms and new customary structures that enabled the negotiation and regulation of the development process (see Banks 2008). Beyond the strict economic mechanisms to which it could be reduced, analysis of the compensation arrangements 
in terms of relationships reveals the strength of the institutions that further optimised local control over natural resources. Thus a form of rent collection and relationship with the industrial concern depends on each of these levels of organisation and negotiation, be it the chieftaincy, the municipality, or the Djubéa-Kapume area as a whole. However, the extension of the discourse of Rhéébu Nùu to the mining tax regime aimed to leave behind this localising logic in favour of considering the mode of industrial development and the meaning of sustainable development. Like the reflection on sustainable development, the 2002 Kanaky Declaration testifies to this desire to consider in their totality the areas being developed or earmarked for development. What is involved, therefore, is the collective consideration of environmental conservation, compensation and the benefits to be gained from mining, at both the local level and that of New Caledonia as a whole.

\section{References}

Ali, S.H., 2009. Mining, the Environment, and Indigenous Development Conflicts. Tucson: University of Arizona Press.

Anon., 2001. '19 Milliards: Le Cher Projet des Coutumiers du Sud.' Les Nouvelles Calédoniennes, 24 July.

—, 2003. 'Gisement de Prony: Les Réactions.' Les Nouvelles Calédoniennes, 26 December.

Bainton, N.A., 2009. 'Keeping the Network Out of View: Mining, Distinctions and Exclusion in Melanesia.' Oceania 79: 18-33. doi.org/ 10.1002/j.1834-4461.2009.tb00048.x

Bainton, N.A. and M. Macintyre, 2013. “"My Land, My Work”: Business Development and Large-Scale Mining in Papua New Guinea.' In F. McCormack and K. Barclay (eds), Engaging with Capitalism: Cases from Oceania. Bingley (UK): Emerald Group Publishing (Research in Economic Anthropology 33). doi.org/10.1108/S01901281(2013)0000033008

Banks, G., 2008. 'Understanding "Resource" Conflicts in Papua New Guinea.' Asia-Pacific Viewpoint 49: 23-34. doi.org/10.1111/j.14678373.2008.00358.x 
Bensa, A., 1992. 'Terre Kanak: Enjeu Politique d'Hier et d'Aujourd'hui: Esquisse d'un Modèle Comparatif.' Etudes Rurales 127-128: 107-131. doi.org/10.3406/rural.1992.3383

__ 2000. 'Le Chef Kanak: Les Modèles et l'Histoire.' In A. Bensa and I. Leblic (eds), En Pays Kanak: Ethnologie, Linguistique, Archéologie, Histoire de la Nouvelle-Calédonie. Paris: Éditions de la Maison des Sciences de l'Homme (Ethnologie de la France 14).

Demmer, C., 2007. 'Autochtonie, Nickel et Environnement en Nouvelle-Calédonie: Une Nouvelle Stratégie Kanake.' Vacarme 39: 43-48. doi.org/10.3917/vaca.039.0043

__ 2012. 'La “Chefferie Minière” en Question: Etude de Cas à Canala.' Nouméa: CNRT Nickel CNRT Nickel, Programme Gouvernance Minière (Document de Travail 13).

Detienne, M., 2003. Comment être Autochtone: Du pur Athénien au Français Raciné. Paris: Seuil.

Djama, M., 2009. 'Politiques de l'Autochtonie en Nouvelle-Calédonie.' In M. Salaün, M. Thibault and N. Gagné (eds), Autochtonies: Vues de France et du Québec. Québec: Presses de l'Université Laval.

Filer, C., 1997. 'Compensation, Rent and Power in Papua New Guinea.' In S. Toft (ed.), Compensation for Resource Development in Papua New Guinea. Boroko (PNG): Law Reform Commission (Monograph 6). Canberra: The Australian National University, National Centre for Development Studies (Pacific Policy Paper 24).

Frédière, P., 2005. 'Raphaël Mapou Réussit sa Sortie du Palais.' Les Nouvelles Calédoniennes, 9 February.

Freyss, J., 1995. Economie Assisteé et Changement Social en NouvelleCalédonie. Paris: Presses Universitaires de France.

Frouin, A.-L., 2010. Revendications de l'Autochtonie et Contrôle des Ressources Naturelles au Sud de la Nouvelle-Calédonie: L'Exemple de la Mobilisation Kanak dans la Commune de Yaté. Université AixMarseille (Masters thesis). 
Graff, S., 2012. 'Quand Combat et Revendications Kanak ou Politique de l'Etat Français Manient Indépendance, Décolonisation, Autodétermination et Autochtonie en Nouvelle-Calédonie.' Journal de la Société des Océanistes 134: 61-83. doi.org/10.4000/jso.6647

Grochain, S., 2007. Les Kanak et le Travail en Province Nord de la Nouvelle-Calédonie. Paris: Ecole des Hautes Etudes en Sciences Sociales ( $\mathrm{PhD}$ thesis).

Horowitz, L.S., 2009. 'Environmental Violence and Crises of Legitimacy in New Caledonia.' Political Geography 28: 248-258. doi.org/10.1016/ j.polgeo.2009.07.001

_ 2010. “'Twenty Years Is Yesterday”: Science, Multinational Mining and the Political Ecology of Trust in New Caledonia.' Geoforum 41: 617-626. doi.org/10.1016/j.geoforum.2010.02.003

— 2012. 'Translation Alignment: Actor-Network Theory, Resistance, and the Power Dynamics of Alliance in New Caledonia.' Antipode 44: 806-827. doi.org/10.1111/j.1467-8330.2011.00926.x

Jacob, J.-P. and P.-Y. Le Meur, 2010. 'Citoyenneté Locale, Foncier, Appartenance et Reconnaissance dans les Sociétés du Sud.' In J.-P. Jacob and P.-Y. Le Meur (eds), Politique de la Terre et de l'Appartenance: Droits Fonciers et Citoyenneté Locale dans les Sociétés du Sud. Paris: Karthala.

Jost, C., 1998. 'Perceptions Sociales et Dimensions Culturelles d'un Nouveau Projet Minier en Nouvelle-Calédonie.' In D. Guillaud, M. Seysset and A. Walter (eds), Le Voyage Inachevé ... A Joël Bonnemaison. Paris: ORSTOM.

Kowasch, M., 2012. 'Le Développement de l'Industrie du Nickel et la Transformation de la Valeur Environnementale en NouvelleCalédonie.' Journal of Political Ecology 19: 202-220.

Le Meur, P.-Y., 2010. 'La Terre en Nouvelle-Calédonie: Pollution, Appartenance et Propriété Intellectuelle.' Multitudes 41: 91-98. doi.org/10.3917/mult.041.0091 
Le Meur, P.-Y., L.S. Horowitz and T. Mennesson, 2013. "'Horizontal" and "Vertical" Diffusion: The Cumulative Influence of Impact and Benefit Agreements (IBAs) on Mining Policy-Production in New Caledonia.' Resources Policy 38: 648-656. doi.org/10.1016/ j.resourpol.2013.02.004

Le Meur, P.-Y. and T. Mennesson, 2011. 'Le Cadre Politico-Juridique Minier en Nouvelle-Calédonie: Mise en Perspective Historique.' Nouméa: CNRT Nickel, Programme Gouvernance Minière (Document de Travail 3).

Loraux, N., 1996. Nés de la Terre. Paris: Seuil.

Mapou, R., 2002. 'Information sur le Massif de Prony.' Journée Mondiale des Peuples Indigènes, 9 August.

Merle, I., 1999. 'La Construction d'un Droit Foncier Colonial: De la Propriété Collective à la Constitution des Réserves en NouvelleCalédonie.' Enquête 7: 97-126. doi.org/10.4000/enquete.1571

Monnerie, D., 2005. La Parole de Notre Maison: Discours et Cérémonies Kanak Aujourd'hui (Nouvelle-Calédonie). Paris: Éditions de la Maison des Sciences de l'Homme.

Morin, F., 2006. 'L'Autochtonie, Forme d'Ethnicité ou Exemple d'Ethnogenèse?' Parcours Anthropologiques 6: 54-64.

Naepels, M., 2006. 'Réforme Foncière et Propriété dans la Région de Houaïlou (Nouvelle-Calédonie).' Etudes Rurales 177: 43-54.

O'Faircheallaigh, C., 2011. 'Use and Management of Revenues from Indigenous-Mining Company Agreements: Theoretical Perspectives.' Melbourne: University of Melbourne, Agreements Treaties and Negotiated Settlements Project (Working Paper 1).

Pitoiset, A. and M. Prandi, 2006. 'Le Projet Néo-Calédonien de Goro Stoppé.' Les Échos, 4 April.

Saada, E., 2003. 'Citoyens et Sujets de l'Empire Français: Les Usages du Droit en Situation Coloniale.' Genèses 53: 4-24. doi.org/10.3917/ gen.053.0004 
Sourisseau, J.-M., S. Bouard, C. Gaillard, P.-Y. Le Meur, T. Mennesson and G. Pestaña, 2015. 'Entre Neutralisation et Requalification: Les Limites de la Diffusion du Référentiel du Développement Durable en Nouvelle-Calédonie.' In S. Blaise, C. David and V. David (eds), Le Développement Durable en Océanie: Vers une Éthique Nouvelle? Marseille: Presses Universitaires de Provence.

Sourisseau, J.-M., S. Bouard and G. Pestaña, 2013. Ruralité et Développement Durable en Nouvelle-Calédonie: Synthèse des Ateliers de Poindimié et Perspectives. Province Nord: IAC Éditions.

Strathern, A., 1993. 'Compensation: What Does It Mean?' TaimLain 1: $57-82$.

Taylor C., 1994. Multiculturalism: Examining the Politics of Recognition. Princeton (NJ): Princeton University Press. 
This text is taken from Large-scale Mines and Local-level Politics: Between New Caledonia and Papua New Guinea, edited by Colin Filer and Pierre-Yves Le Meur, published 2017 by ANU Press, The Australian National University, Canberra, Australia. 